\title{
Apatite formation on calcined kaolin-white Portland cement geopolymer
}

\author{
S. Pangdaeng a, V. Sata ${ }^{\text {a }}$ J.B. Aguiar ${ }^{\text {b }}$, F. Pacheco-Torgal ${ }^{\text {b }}$, P. Chindaprasirt ${ }^{\mathrm{a}, *}$ \\ a Sustainable Infrastructure Research and Development Center, Department of Civil Engineering, Faculty of Engineering, Khon Kaen University, Khon Kaen 40002, Thailand \\ b C-TAC Research Centre, Department of Civil Engineering, University of Minho, Campus of Azurém, 4800-058 Guimarães, Portugal
}

\section{A R T I C L E I N F O}

\section{Article history:}

Received 20 October 2014

Received in revised form 16 January 2015

Accepted 24 February 2015

Available online 25 February 2015

\section{Keywords:}

Geopolymer

Apatite

Simulated body fluid

Kaolin

White Portland cement

\begin{abstract}
A B S T R A C T
In this study, calcined kaolin-white Portland cement geopolymer was investigated for use as biomaterial. Sodium hydroxide and sodium silicate were used as activators. In vitro test was performed with simulated body fluid (SBF) for bioactivity characterization. The formation of hydroxyapatite bio-layer on the 28-day soaked samples surface was tested using SEM, EDS and XRD analyses. The results showed that the morphology of hydroxyapatite was affected by the source material composition, alkali concentration and curing temperature. The calcined kaolin-white Portland cement geopolymer with relatively high compressive strength could be fabricated for use as biomaterial. The mix with 50\% white Portland cement and 50\% calcined kaolin had 28-day compressive strength of $59.0 \mathrm{MPa}$ and the hydroxyapatite bio-layer on the 28-day soaked sample surface was clearly evident.
\end{abstract} (c) 2015 Elsevier B.V. All rights reserved.

\section{Introduction}

A geopolymer is a three-dimensional aluminosilicate network formed by polycondensation of monomers $-\mathrm{OSi}(\mathrm{OH})_{3}$ and $\mathrm{Al}(\mathrm{OH})_{4}$ [1]. In the presence of high alkaline solution, $\mathrm{SiO}_{2}$ and $\mathrm{Al}_{2} \mathrm{O}_{3}$ from source materials leach out and react to form a geopolymer. Several source materials such as calcined kaolin, fly ash, bottom ash, and slag are used as starting materials to obtain high strength geopolymers [2-4]. Portland cement is also successfully used as a source material to produce geopolymer as it contains high silica and alumina [5]. To use geopolymer material as biomaterial, clean source material with minimum contamination is needed. Calcined kaolin (CK) with white color seems to be the best source material for this purpose. For the blend of source material, white Portland cement (WPC) with low iron and magnesium oxide obtained from specific process and fuel used in clinker manufacture [6] is a preferred choice.

Investigations of bioactivity on the surface of cementitious material such as WPC [7,8] and aluminosilicate/inorganic polymer [9-12] have been studied. Apatite-like layer forming on calcium silicate based material from WPC has been reported [7,8,13]. These bio-reactive apatite-like layers such as hydroxyapatite (HA) and hydroxyl carbonate apatite (HCA) are responsible for bone bonding [14]. In the system, the leached calcium hydroxide gives a high $\mathrm{pH}$ condition and enhances the apatite precipitations with the presence of calcium ions [8]. A high $\mathrm{Si}-\mathrm{OH}$

\footnotetext{
* Corresponding author.

E-mail address: prinya@kku.ac.th (P. Chindaprasirt).
}

group in calcium silicate materials promotes the HA precipitation through the increased nucleation sites [15]. For aluminosilicate/inorganic polymer, the studies on bioactive functional group on its surface were presented for both in vivo and in vitro studies [9-12,16]. However in this system, the high alkalinity condition was not conducive for the existence of HA and the cell [17]. For CK geopolymer, a study has indicated that the condition is not favorable for the formation of bioactive HA [16]. Therefore, co-existence of both calcium compound and $\mathrm{Si}-\mathrm{OH}$ group is probably the favorable condition for precipitation of bioactive hydroxyapatite layer on the surface of materials. In addition, it has been reported that the curing temperature at $250-625{ }^{\circ} \mathrm{C}$ of aluminosilicate materials lowers the $\mathrm{pH}$ from 10 to 7 and renders the condition more biocompatible [18].

A number of researches on aluminosilicate material application for bone repair cement have been carried out, but poor strength and low bioactivity are still problems [9-12,19]. Previous works reported the enhancement of mechanical properties of geopolymer matrixes with the incorporation of Portland cement [20]. High compressive strength is preferable for material used for bone substitution. Moreover, both Portland cement and CK geopolymer contain calcium and $\mathrm{Si}-\mathrm{OH}$ functional compounds. These compounds promote the precipitation of bioactive layer-like HA on the material surface [21].

In this paper, the CK-WPC geopolymer was fabricated and tested for use as a bone-like material with suitable strength and bioactivity function. Simulated body fluid (SBF) was used to investigate the bioactivity of materials. The formation of bioactive layer-like HA was characterized with the aids of scanning electron microscopy (SEM), energy dispersive spectrometry (EDS) and X-ray diffraction (XRD) techniques. 
Table 1

Chemical composition of CK and WPC.

\begin{tabular}{|c|c|c|c|c|c|c|c|c|c|c|}
\hline \multirow[t]{2}{*}{ Materials } & \multicolumn{8}{|c|}{ Chemical composition (\%) } & \multirow[t]{2}{*}{ Blaine fineness $\left(\mathrm{cm}^{2} / \mathrm{g}\right)$} & \multirow[t]{2}{*}{ Specific gravity } \\
\hline & $\mathrm{SiO}_{2}$ & $\mathrm{Al}_{2} \mathrm{O}_{3}$ & $\mathrm{CaO}$ & $\mathrm{Fe}_{2} \mathrm{O}_{3}$ & $\mathrm{MgO}$ & $\mathrm{Na}_{2} \mathrm{O}$ & $\mathrm{SO}_{3}$ & $\overline{\mathrm{LOI}^{\mathrm{a}}}$ & & \\
\hline CK & 59.7 & 34.1 & 0.1 & 0.9 & 0.2 & 0.2 & 0.1 & 1.2 & 13,800 & 2.59 \\
\hline WPC & 15.9 & 1.9 & 73.5 & 0.2 & 0.9 & 0.0 & 4.9 & 2.3 & 3430 & 3.10 \\
\hline
\end{tabular}

a LOI $=$ loss on ignition.

\section{Materials and methods}

\subsection{Sample preparation}

CK and WPC were used as source materials in this experiment. Their main chemical compositions are shown in Table 1. WPC contains a high amount of $\mathrm{CaO}$ (73.5\%) and $\mathrm{CK}$ contained a high amount of $\mathrm{SiO}_{2}(59.7 \%)$ and $\mathrm{Al}_{2} \mathrm{O}_{3}$ (34.1\%). Geopolymer samples were prepared with liquid/ binder ratio of 1.0 . Sodium hydroxide $(\mathrm{NH}, 10 \mathrm{M})$ and sodium silicate (NS, $15.32 \% \mathrm{Na}_{2} \mathrm{O}, 32.87 \% \mathrm{SiO}_{2}$ and $51.81 \% \mathrm{H}_{2} \mathrm{O}$ ) with $\mathrm{NH} / \mathrm{NS}$ ratio of 1.0 were used. The geopolymer pastes with CK:WPC by weight of 100:0, 75:25, 50:50, 25:75 and 0:100 (PC0, PC25, PC50, PC75 and PC100) were prepared. Paste samples were cast in $25 \mathrm{~mm}^{3}$ acyclic molds for compressive strength test and in $10 \mathrm{~mm}$ diameter and $2 \mathrm{~mm}$ disc molds for bioactivity test. Samples were wrapped with plastic film to protect moisture loss and were left for $1 \mathrm{~h}$ in a $23^{\circ} \mathrm{C}$ room and then cured at $23^{\circ} \mathrm{C}$ and $60^{\circ} \mathrm{C}$ for $24 \mathrm{~h}$. The samples were then demolded, wrapped with plastic film and stored in a $23{ }^{\circ} \mathrm{C}$ controlled room.

\subsection{Test method}

Immediately after the mixing of the geopolymer pastes, the initial and final setting times of pastes were measured using Vicat apparatus in accordance with ASTM C191 [24]. Compressive strengths of geopolymer pastes at the age of 7 days were tested in accordance with ASTM C109 [25]. Three $25 \mathrm{~mm}$ cube samples were used for the compressive strength test and the reported results were the average values. The relative $\mathrm{pH}$ values of hardened geopolymer pastes were also tested using $15 \mathrm{mg}$ of paste ground and mixed with $150 \mathrm{~cm}^{3}$ distilled water [26]. For apatite formation characterization, the soaked samples were dried in a desiccator and the surface structures were studied using JEOL JEM-5910LV scanning electron microscopy (SEM). The chemical compositions of the products were analyzed using energy dispersive spectrometry (EDS). The formed apatite layer was confirmed by crystallography technique using X-ray diffraction (XRD) method between $15.0-59.9916^{\circ} 2 \theta$ with $0.0229^{\circ}$ step and step time of $240.5 \mathrm{~s}$.

\subsection{In vitro test}

Simulated body fluid (SBF) with ion concentration similar to human blood plasma was prepared in accordance with the method given by Kokubo [22]. At the age of 7 days, the geopolymer paste discs were submerged in SBF solution in sealed plastic containers and controlled soaking environment of $37^{\circ} \mathrm{C}$. The contact disc surface area to solution volume ratio was $0.1 \mathrm{~cm}^{-1}$ [23]. Soaking duration was 28 days to allow the formation of apatite layer on the sample surface. The $\mathrm{pH}$ levels of solutions were also monitored at 1, 3, 6, 12, $24 \mathrm{~h}$ and 7, 14, and 28 days. After removal from SBF, samples were gently washed with distilled water and kept dry in the desiccator. The SBF was not refreshed during the 28 day soaking period in order to lessen the chance of disturbing the samples.

\section{Results and discussions}

\subsection{Properties of geopolymer}

The results of setting times of CK-WC geopolymer pastes are shown in Table 2 and illustrated in Fig. 1a. The initial and final setting times of
$\mathrm{CK}$ geopolymer were reasonable at 47 and $72 \mathrm{~min}$. The incorporation of $25 \%$ WPC did not reduce both initial and final setting times of the geopolymer pastes. For increased incorporation of $50 \%$ and beyond, the initial and final setting times of pastes were reduced. For example, the initial setting times of geopolymer pastes with $0,25,50,75$ and $100 \%$ WPC were 47, 47, 35, 26 and 20 min, respectively. The reduction was due to the increase in calcium content as WPC contained a high $\mathrm{CaO}$ content $(73.4 \%)$. The increase in calcium in the system, through the provision of extra nucleation sites for precipitation of dissolved species [27], significantly accelerated the setting and hardening of the geopolymer $[20,28]$. The calcium hydration products were formed and co-existed with the geopolymer products [29]. The fast setting of cement binders is desirable for bone repair material and dental cement [30].

The results of the strength of geopolymer pastes as shown in Table 2 and Fig. $1 \mathrm{~b}$ showed that the strength was affected by the incorporation of WPC and curing temperature. The compressive strengths of geopolymer pastes cured at 23 and $60{ }^{\circ} \mathrm{C}$ were 45.4 and $49.9 \mathrm{MPa}$, respectively. High curing temperature of the geopolymer accelerates the strength development at the early age [31]. In this case, the difference in strength was not large as the alkali activation of CK was an endothermic process [32] and the geopolymerization of CK could thus proceed with the ambient $23^{\circ} \mathrm{C}$ curing temperature. In addition, the incorporation of a proper amount of WPC increased the strength of the geopolymer. The strength of the $\mathrm{CK}$ geopolymer cured at $23{ }^{\circ} \mathrm{C}$ was 45.4 $\mathrm{MPa}$ and improved to $63.8 \mathrm{MPa}$ with the incorporation of $50 \%$ WPC. Optimum calcium in geopolymerization caused the precipitation of calcium components viz., calcium silicate hydrate and calcium hydroxide and led to high compressive strengths [27,33]. However, a high amount of WPC resulted in the reduction of compressive strength as the development of $\mathrm{C}-\mathrm{S}-\mathrm{H}$ was retarded due to the rapid removal of available Si from geopolymer formation [5]. For curing at $60{ }^{\circ} \mathrm{C}$, the optimum WPC of $50 \%$ was also observed with optimum strength of $55.0 \mathrm{MPa}$. In this case, the increase in strength was not as large as the case of $23{ }^{\circ} \mathrm{C}$ curing. For high WPC content of 50\%, the compressive strength gain was significant at the early age and noticeably slowed down at the later age [34]. High curing temperature adversely affected the strength development at the later age due to the modifications of microstructure of hydration products [35].

The results of the test of relative $\mathrm{pH}$ of geopolymer pastes are shown in Table 2. The relative $\mathrm{pH}$ values of geopolymer pastes increased with the increase in WPC content. The mixes with $0,25,50,75$ and $100 \%$ WPC cured at $23{ }^{\circ} \mathrm{C}$ resulted in the relative $\mathrm{pH}$ values of 10.2 , $10.6,11.1,11.2$ and 11.6 , respectively. Similar increases were also observed for the samples cured at $60{ }^{\circ} \mathrm{C}$. An increase in $\mathrm{pH}$ was caused

Table 2

Properties of geopolymer pastes.

\begin{tabular}{|c|c|c|c|c|c|c|c|c|}
\hline \multirow[t]{2}{*}{ Mix } & \multirow{2}{*}{$\begin{array}{l}\text { CK } \\
\overline{\text { (wt.\%) }}\end{array}$} & \multirow{2}{*}{$\begin{array}{l}\text { WPC } \\
\overline{\text { (wt.\%) }}\end{array}$} & \multicolumn{2}{|c|}{$\begin{array}{l}\text { Setting time } \\
\text { (minutes) }\end{array}$} & \multicolumn{2}{|c|}{$\begin{array}{l}\text { Compressive } \\
\text { strength } \\
(\mathrm{MPa})\end{array}$} & \multicolumn{2}{|c|}{$\mathrm{pH}$ of pastes } \\
\hline & & & Initial & Final & $23{ }^{\circ} \mathrm{C}$ & $60^{\circ} \mathrm{C}$ & $23^{\circ} \mathrm{C}$ & $60{ }^{\circ} \mathrm{C}$ \\
\hline PCO & 100 & 0 & 47 & 72 & 45.4 & 49.9 & 10.2 & 9.8 \\
\hline PC25 & 75 & 25 & 47 & 91 & 51.3 & 48.9 & 10.6 & 10.6 \\
\hline PC50 & 50 & 50 & 35 & 67 & 63.8 & 55.0 & 11.1 & 11.0 \\
\hline PC75 & 25 & 75 & 26 & 48 & 35.9 & 30.5 & 11.2 & 11.2 \\
\hline PC100 & 0 & 100 & 20 & 35 & 14.6 & 10.6 & 11.6 & 11.7 \\
\hline
\end{tabular}




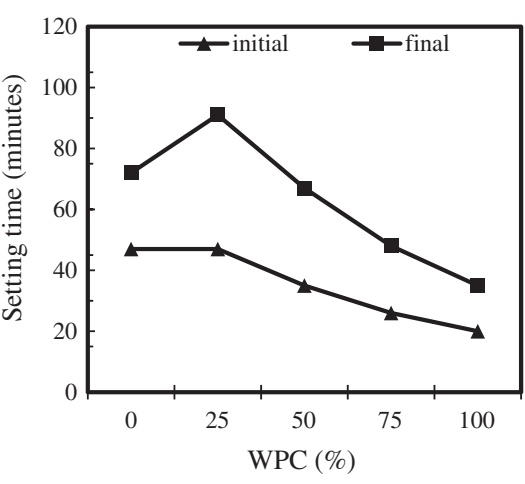

(a) Setting time

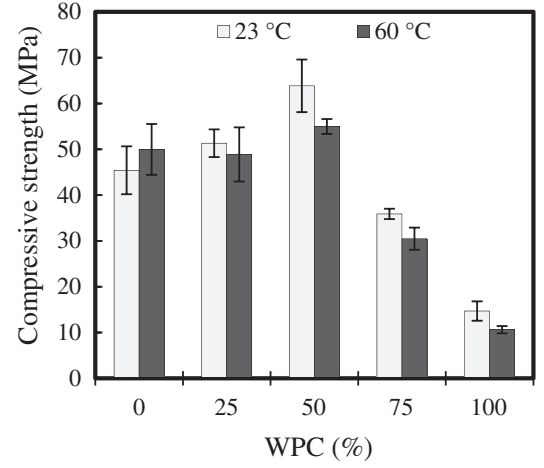

(b) Compressive strength at 7 days

Fig. 1. Setting time and compressive strength of geopolymer pastes.

by the increased amount of calcium since it reacted and formed calcium hydration products that created greater alkalinity than those obtained from geopolymerization [17].

\subsection{Bioactivity}

Bioactivity property of the geopolymer was indicated by the $\mathrm{pH}$ change of SBF solution after immersion. The measured pH of SBF increased with soaking time. High $\mathrm{pH}$ level was observed for mixes with high WPC content as shown in Fig. 2. The initial increases in pH of SBF solutions were noticeably different. The mix with $100 \%$ PC showed a high initial rate of increase of $\mathrm{pH}$ and a small tendency to increase after $24 \mathrm{~h}$ of soaking. On the other hand, the mix with 0\% PC displayed a low initial rate of increase and also a small tendency to increase after $24 \mathrm{~h}$ of soaking. With regard to different curing methods, higher curing temperature at $60^{\circ} \mathrm{C}$ obviously showed lower $\mathrm{pH}$ increment than those with $23^{\circ} \mathrm{C}$ curing. The increase in $\mathrm{pH}$ of SBF was caused by the dissolution of $\mathrm{Ca}(\mathrm{OH})_{2}$ from the geopolymer paste and contributed to the high alkalinity environment [8]. The high curing temperature increased the degree of geopolymerization and strength of paste [31]. For curing at low temperature, the geopolymerization was less advanced resulting in pastes with lower strengths with the remains of some alkali liquid in the gel and matrix pores [36]. This resulted in the high relative $\mathrm{pH}$ values for mixes with low temperature curing.

The surface morphology by SEM of samples soaked for 28 days is displayed in Fig. 3. For $23{ }^{\circ} \mathrm{C}$ curing, the mix with $0 \%$ PC showed no bio-layer formed on the surface as presented in Fig. 3a. However, for the PC25 mix, only a small amount of particles (both spherical and non-spherical shapes) was found deposited at the surface of the sample. For higher WPC content mix (PC50), the deposition of spherical particles of approximately $1 \mu \mathrm{m}$ in diameter was clearly observed. The formed spherical particles were identified as the HA apatite bio-layer as indicated by the EDS spectrum of calcium and phosphate $[7,37,38]$ on high magnification SEM as shown in Fig. 4b and c. For the PC100 mix, a small amount of spherical particles was also found at the surface of the sample as shown in Fig. 3a.

For $60{ }^{\circ} \mathrm{C}$ curing, the formation of apatite was observed for mixes PC25, PC50 and PC100 as shown in Fig. 3b. The morphology of apatite on PC50 and PC100 surfaces was significantly different from that of the low temperature curing. The apatite layer of the PC50 sample was dense as displayed in Fig. 4c. It should be noted that, when the sample contacted SBF solution, the alkali ions leached out and resulted in high concentration of ions near the contact surface and supersaturation of SBF. This limited the ability of calcium and negative phosphate ion dissolutions and finally affected the growth of HA formation. Furthermore, it has been shown that the pore volume as measured by mercury intrusion porosimetry slightly increases with increasing temperature of curing [31]. With the increase of pore volume, the release of $\mathrm{OH}^{-}$usually will be promoted. However, for the curing at high temperature, the increase in pore volume occurred in conjunction with the increase in strength and micro-structural development of paste and thus the release of $\mathrm{OH}^{-}$was reduced. The enlarged pore size and pore volume of paste led to a higher contact area to SBF solution and increased the leaching of calcium ions from calcium hydroxide and produced biocompatible calcium carbonate. Large amounts of calcium carbonate (calcite) on PC50 and PC100 samples with $60{ }^{\circ} \mathrm{C}$ heat curing were evident as observed by the XRD analysis (Fig. 5). Similar HA induction on heattreated surface was demonstrated for $\mathrm{CaO}$ containing titanium $[37,39]$. For the PC100 mix, SEM results indicated the presence of apatite particles of approximately $1 \mu \mathrm{m}$ in diameter as shown in Fig. 4d.

Fig. 5 shows the XRD pattern of PC100 and PC50 samples with 23 and $60{ }^{\circ} \mathrm{C}$ curing. The graphs showed HA observation on samples. Calcium phosphate was located by the prominent peaks at 25.1, 31.6 and $49.4^{\circ} 2 \theta$. Calcite $\left(\mathrm{CaCO}_{3}\right)$ was also detected by high peak in the PC50 mix cured at $60{ }^{\circ} \mathrm{C}$ and the amount was lower in the same mix cured at $23{ }^{\circ} \mathrm{C}$. A high amount of calcite was also presented in the PC100 mix cured at $60{ }^{\circ} \mathrm{C}$. In addition, calcium silicate $\left(\mathrm{Ca}_{3} \mathrm{SiO}_{5}\right)$ was detected at $32.5^{\circ} 2 \theta$ in both PC50 and PC100 mixes with $60{ }^{\circ} \mathrm{C}$ curing. As this peak

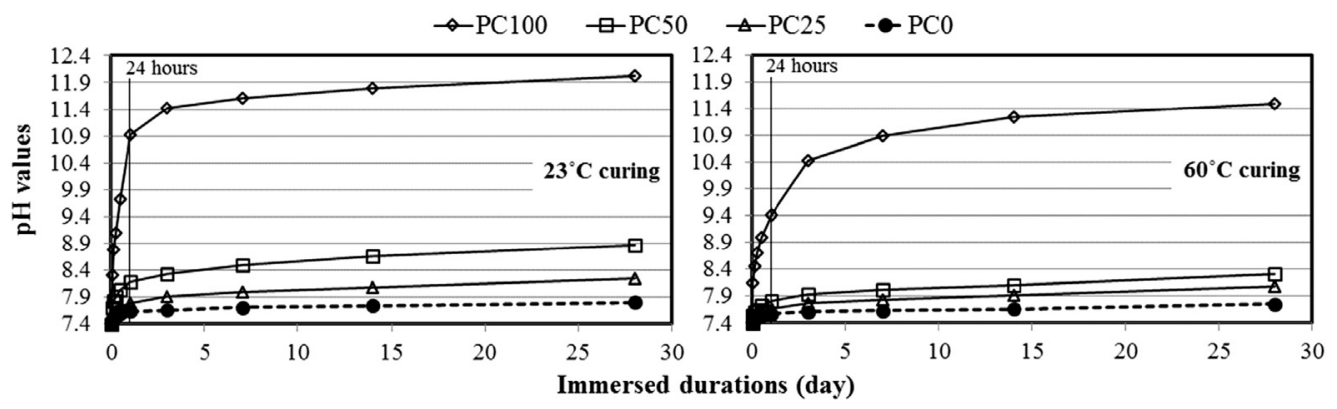

Fig. 2. pH values of SBF at different intervals of soaking of geopolymer disc. 


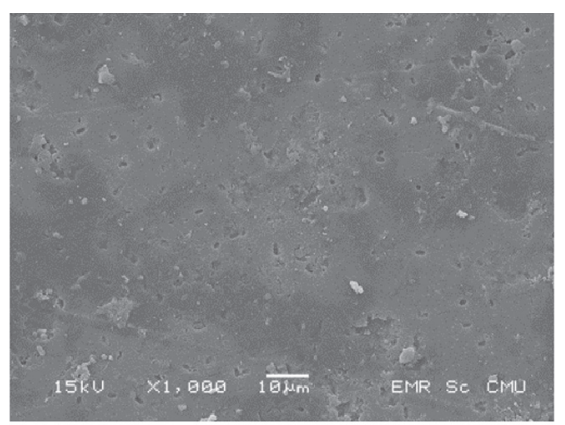

PC0

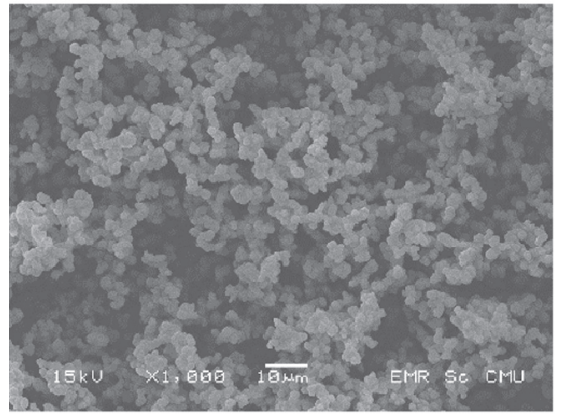

PC50

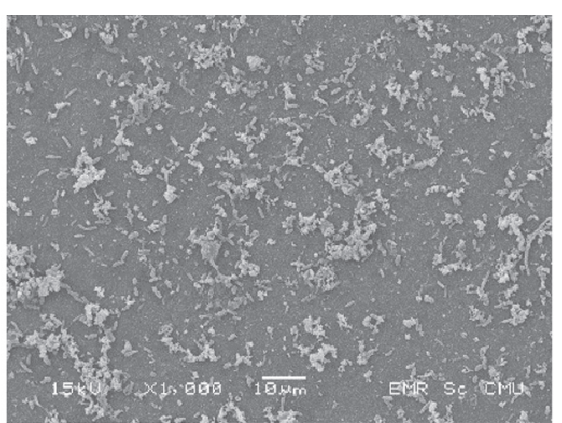

PC25

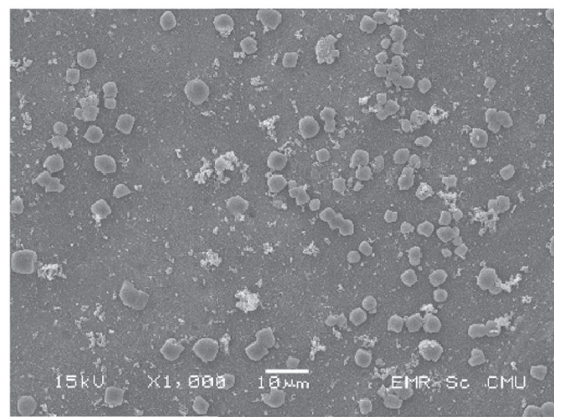

PC100

\section{(a) $23^{\circ} \mathrm{C}$ curing}

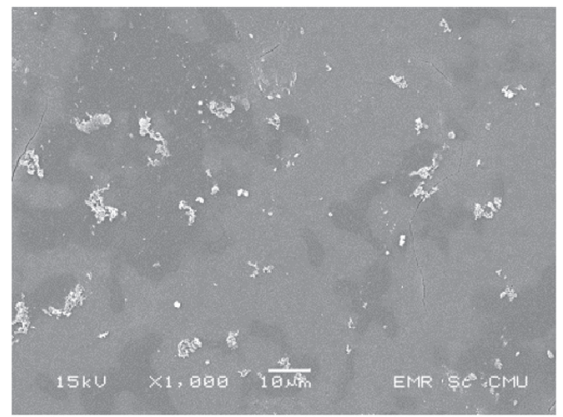

PC0

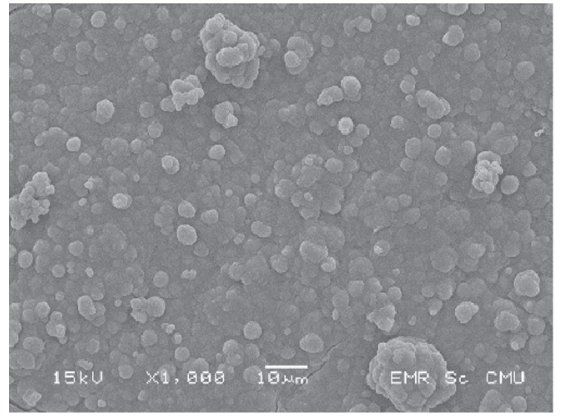

PC50

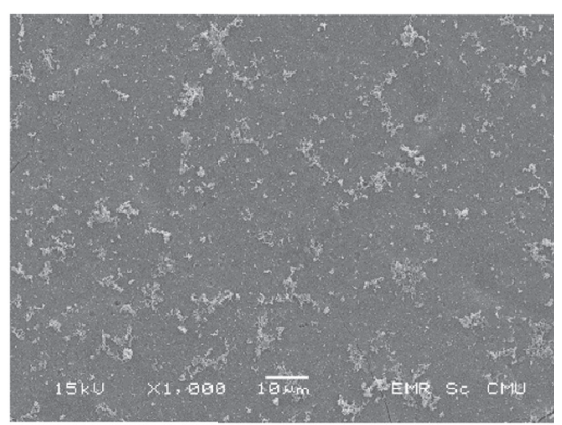

PC25

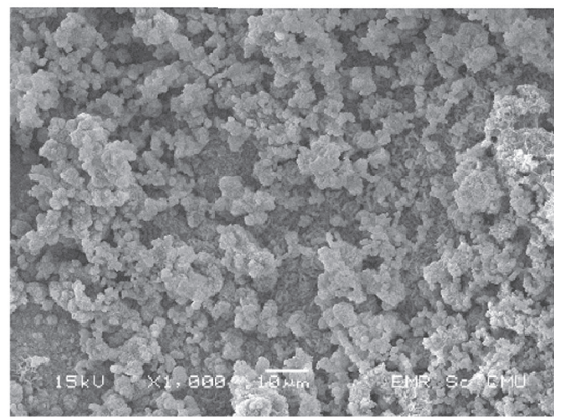

PC100

(b) $60^{\circ} \mathrm{C}$ curing

Fig. 3. SEM images of geopolymer pastes after 28 days in SBF.

was near the $31.6^{\circ}$ peak of calcium phosphate, the clarity of the two peaks was thus hindered. Another observed peak was quartz $\left(\mathrm{SiO}_{2}\right)$ in the PC50 mix which was from the unreacted CK in the system. The addition of WPC increased calcium ions into the geopolymer system and contributed to the precipitation of HA on the sample surfaces. The HA crystal formed on geopolymer surface showed main characteristic peaks similar to that reported by previous work [40].
The in vitro test of the CK-WPC geopolymer soaked in SBF solution indicated good bioactivity. Calcium hydroxide $\left(\mathrm{Ca}(\mathrm{OH})_{2}\right)$ reacted with SBF and released calcium ions into SBF solution [41] and further transformed to calcium carbonate $\left(\mathrm{CaCO}_{3}\right)$ with good bioactivity [8]. Moreover, the $\mathrm{Si}-\mathrm{OH}$ in geopolymer products promoted the forming ability of HA layer on its surface since the formation of HA layer depended on the content of $\mathrm{Ca}^{2+}$ ions and silicate groups at the sample surface [42, 

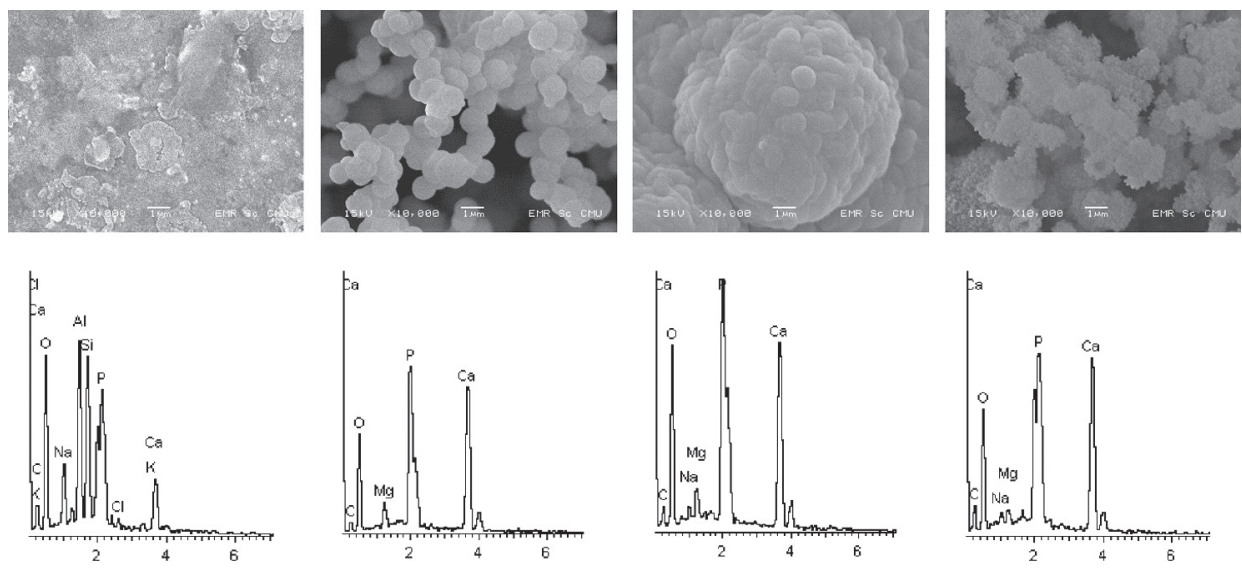

(a) $\mathrm{PC} 023^{\circ} \mathrm{C}$
cured

(b) $\mathrm{PC} 5023^{\circ} \mathrm{C}$

cured

(c) $\mathrm{PC} 5060^{\circ} \mathrm{C}$

cured (d) $\mathrm{PC} 10060^{\circ} \mathrm{C}$

cured

Fig. 4. SEM and EDS analyses of apatite formed on geopolymer surfaces after soaking in SBF.

43]. Possible explanation of behavior was given in the literatures $[10,44$, 45 ] that when sodium aluminosilicate materials contacted SBF, $\mathrm{Na}^{+}$ ions leached out and reacted with $\mathrm{H}_{3} \mathrm{O}^{+}$in $\mathrm{SBF}$ and formed $\mathrm{Si}-\mathrm{OH}$ and $\mathrm{Al}-\mathrm{OH}$ groups on its surface and dissociated to $\mathrm{Si}-\mathrm{O}-$ negative functional group. This reaction caused a slight increase in $\mathrm{pH}$ value. Consequently, the presence of positive charges of $\mathrm{Ca}^{2+}$ in the fluid combined with those groups and imposed an increase of positive charge on the surface and promoted the $\mathrm{Ca}^{2+}$ to combine with negative charges of phosphate ions to spontaneously form hydroxyapatite. Moreover, leached
$\mathrm{Ca}^{2+}$ ions also enhanced the super-saturation of SBF and enhanced the HA layer formation [8]. The bioactivity of geopolymer cement system was shown to be improved by the addition of WPC.

The results from this study indicated that the CK-WPC geopolymer paste showed promising properties for use as biomaterial. However, it should also be pointed out that the release of $\mathrm{OH}^{-}$from the material can cause severe cytotoxic effects to cells. Therefore, further cytotoxic study is suggested for this CK-WPC geopolymer for application as biomaterial.

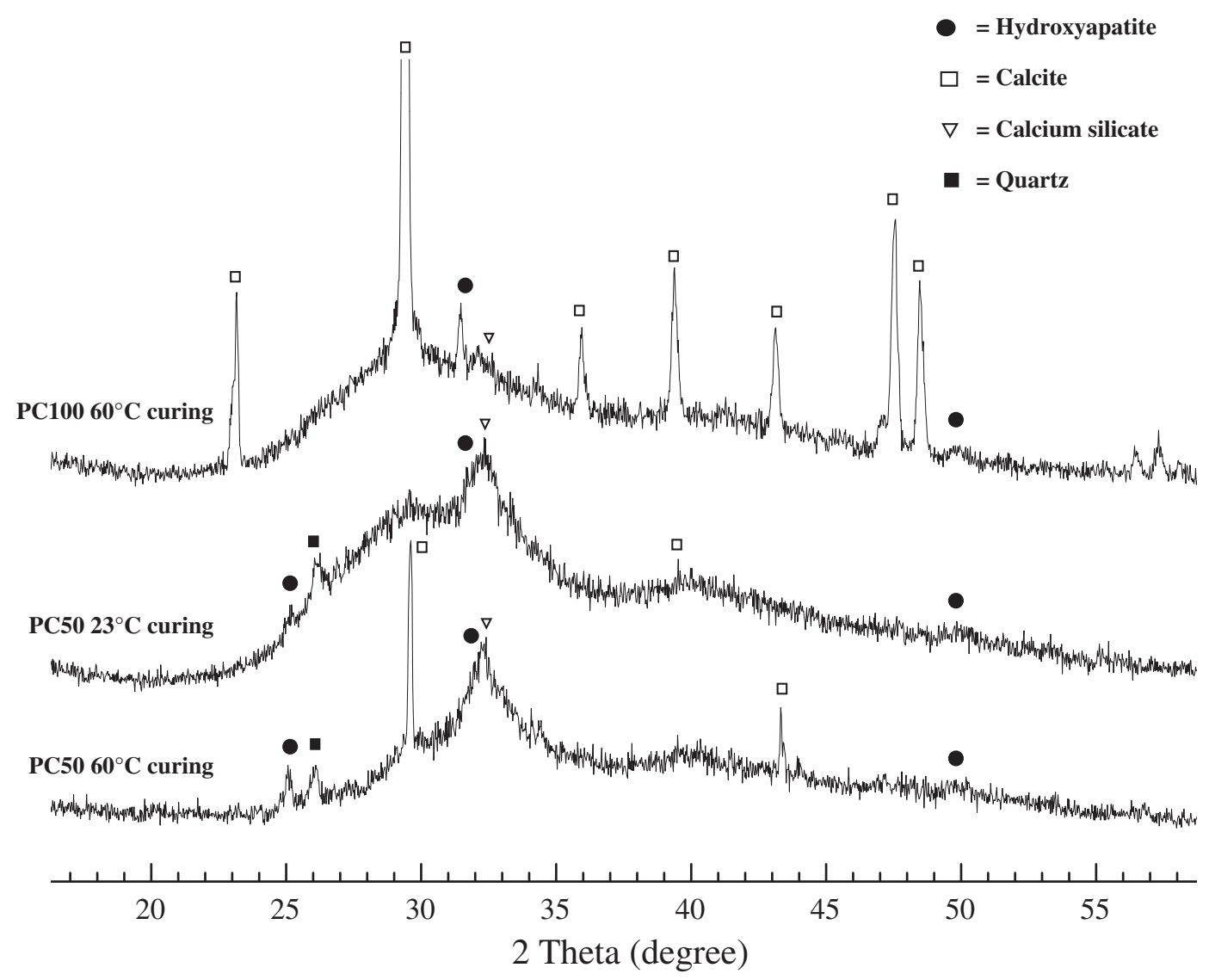

Fig. 5. XRD of hydroxyapatite formed on geopolymer surfaces after soaking in SBF. 


\section{Conclusions}

The addition of appropriate portion of white Portland cement into the calcined kaolin geopolymer system enhanced the mechanical properties of the geopolymer and provided a suitable bone repair and implant material in terms of rapid setting and high compressive strength. The addition of 50\% WPC into the system increased the calcium compounds in the geopolymer matrices and enhanced the performance of geopolymer pastes. When exposed to SBF, the geopolymer exhibited good bioactivity. A large amount of hydroxyapatite bio-layer obviously formed on the matrix surfaces. The curing at $60{ }^{\circ} \mathrm{C}$ resulted in the reduction of $\mathrm{pH}$ of SBF solution and promoted the precipitation of hydroxyapatite on blended geopolymer surface compared to the samples cured at $23^{\circ} \mathrm{C}$.

\section{Acknowledgments}

This work was financially supported by the Thailand Research Fund (TRF) and Khon Kaen University under the TRF-Royal Golden Jubilee Ph.D. program (Grant No. PHD/0143/2554) and TRF-Senior Research Scholar (Grant No. RTA5780004).

\section{References}

[1] A. Buchwald, H.D. Zellmann, C. Kaps, Condensation of aluminosilicate gels-model system for geopolymer binders, J. Non-Cryst. Solids 357 (5) (2011) 1376-1382.

[2] Y.M. Liew, et al., Processing and characterization of calcined kaolin cement powder, Constr. Build. Mater. 30 (2012) 794-802.

[3] V. Sata, A. Sathonsaowaphak, P. Chindaprasirt, Resistance of lignite bottom ash geopolymer mortar to sulfate and sulfuric acid attack, Cem. Concr. Compos. 34 (5) (2012) 700-708.

[4] P. Duxson, et al., Geopolymer technology: the current state of the art, J. Mater. Sci. 42 (9) (2007) 2917-2933.

[5] J. Tailby, K.J.D. MacKenzie, Structure and mechanical properties of aluminosilicate geopolymer composites with Portland cement and its constituent minerals, Cem. Concr. Res. 40 (5) (2010) 787-794.

[6] K.K. Veiga, A.L.G. Gastaldini, Sulfate attack on a white Portland cement with activated slag, Constr. Build. Mater. 34 (2012) 494-503.

[7] A. Chaipanich, P. Torkittikul, Microstructure: surface and cross-sectional studies of hydroxyapatite formation on the surface of white Portland cement paste in vitro, Appl. Surf. Sci. 257 (20) (2011) 8385-8390.

[8] N.J. Coleman, J.W. Nicholson, K. Awosanya, A preliminary investigation of the in vitro bioactivity of white Portland cement, Cem. Concr. Res. 37 (11) (2007) 1518-1523.

[9] S. Martin, et al., Implantation of aluminosilicate/calcium phosphate materials: influence on bone formation in rabbit tibias, Eur. Cells Mater. 9 (1) (2005) 71-72.

[10] M. Catauro, et al., Mechanical and Biological Characterization of Geopolymers for Potential Application as Biomaterials, AZojomo, 2012.

[11] H. Oudadesse, et al., Surface and interface investigation of aluminosilicate biomaterial by the "in vivo" experiments, Appl. Surf. Sci. 255 (2) (2008) 593-596.

[12] M. Todea, et al., Surface structure changes on aluminosilicate microspheres at the interface with simulated body fluid, Corros. Sci. 54 (2012) 299-306

[13] P. Torkittikul, A. Chaipanich, Investigation of the mechanical and in vitro biological properties of ordinary and white Portland cements, ScienceAsia 35 (2009) 358-364.

[14] M. Mami, et al., Investigation of the surface reactivity of a sol-gel derived glass in the ternary system $\mathrm{SiO}_{2}-\mathrm{CaO}-\mathrm{P}_{2} \mathrm{O}_{5}$, Appl. Surf. Sci. 254 (22) (2008) 7386-7393.

[15] L.L. Hench, Biomaterials: a forecast for the future, Biomaterials 19 (16) (1998) 1419-1423.

[16] K.D. MacKenzie, et al., Calcium-containing inorganic polymers as potential bioactive materials, J. Mater. Sci. 45 (4) (2010) 999-1007.

[17] D. Gallego, et al., Bioactive coatings on Portland cement substrates: surface precipitation of apatite-like crystals, Mater. Sci. Eng. C 28 (3) (2008) 347-352.
[18] H. Oudadesse, et al., MAS-NMR studies of geopolymers heat-treated for applications in biomaterials field, J. Mater. Sci. 42 (9) (2007) 3092-3098.

[19] J. Leivo, et al., Sol-gel derived aluminosilicate coatings on alumina as substrate for osteoblasts, Acta Biomater. 2 (6) (2006) 659-668.

[20] S. Pangdaeng, et al., Influence of curing conditions on properties of high calcium fly ash geopolymer containing Portland cement as additive, Mater. Des. 53 (2014) 269-274.

[21] M. Nilsson, et al., Characterization of a novel calcium phosphate/sulphate bone cement, J. Biomed. Mater. Res. 61 (4) (2002) 600-607.

[22] T. Kokubo, H. Takadama, How useful is SBF in predicting in vivo bone bioactivity? Biomaterials 27 (15) (2006) 2907-2915.

[23] D.C. Greenspan, J.P. Zhong, G.P. LaTorre, in: O.H. Andresson, A. Yli-Urpo (Eds.), Effect of Surface Area to Volume Ratio In Vitro Surface Reactions of Bioactive Glass Particulates, Butterworth-Heinemann Ltd., Turku, Finland, 1994.

[24] ASTM C191, Standard Test Method for Time of Setting of Hydrualic Cement by Vicat Needle, American Society for Testing and Materials, Annual Book of ASTM Standard, 2005, pp. 179-185.

[25] ASTM C109, Standard test method of compressive strength of hydraulic cement mortars (using 2-in. or [50 mm] cube specimens), American Society for Testing and Materials, Annual Book of ASTM Standard, 2005, pp. 76-81.

[26] A.C. Derrien, et al., Thermal behaviour of composites aluminosilicate-calcium phosphates, J. Therm. Anal. Calorim. 75 (3) (2004) 937-946.

[27] W.K.W. Lee, J.S.J. van Deventer, The effects of inorganic salt contamination on the strength and durability of geopolymers, Colloids Surf. A Physicochem. Eng. Asp. $211(2-3)(2002)$ 115-126.

[28] P. Chindaprasirt, et al., Effect of $\mathrm{SiO}_{2}$ and $\mathrm{Al}_{2} \mathrm{O}_{3}$ on the setting and hardening of high calcium fly ash-based geopolymer systems, J. Mater. Sci. 47 (12) (2012) 4876-4883.

[29] K. Somna, et al., NaOH-activated ground fly ash geopolymer cured at ambient temperature, Fuel 90 (6) (2011) 2118-2124

[30] M.P. Ginebra, T. Traykova, J.A. Planell, Calcium phosphate cements as bone drug delivery systems: a review, J. Control. Release 113 (2) (2006) 102-110.

[31] P. Rovnaník, Effect of curing temperature on the development of hard structure of metakaolin-based geopolymer, Constr. Build. Mater. 24 (7) (2010) 1176-1183.

[32] Sotya Astutiningsih, H.W. A, Hendra Widhatra, Kresnadya Desha Rousstia, Maria Elizabeth Suryatriyastuti, Utilization of concrete waste aggregates using geopolymer cement, J. Civ. Eng. Archit. 4 (6) (2010) 11-15.

[33] J. Temuujin, A. van Riessen, R. Williams, Influence of calcium compounds on the mechanical properties of fly ash geopolymer pastes, J. Hazard. Mater. 167 (1-3) (2009) 82-88.

[34] F. Pacheco-Torgal, J.P. Castro-Gomes, S. Jalali, Investigations on mix design of tungsten mine waste geopolymeric binder, Constr. Build. Mater. 22 (9) (2008) 1939-1949.

[35] Y. Maltais, J. Marchand, Influence of curing temperature on cement hydration and mechanical strength development of fly ash mortars, Cem. Concr. Res. 27 (7) (1997) 1009-1020.

[36] X. Yao, et al., Geopolymerization process of alkali-metakaolinite characterized by isothermal calorimetry, Thermochim. Acta 493 (1-2) (2009) 49-54.

[37] X.J. Wang, et al., In vitro bioactivity evaluation of titanium and niobium metals with different surface morphologies, Acta Biomater. 4 (5) (2008) 1530-1535.

[38] P. Li, et al., Apatite formation induced on silica gel in a simulated body fluid, J. Am. Ceram. Soc. 75 (1992) 2094-2097.

[39] M. Wei, et al., Apatite-forming ability of $\mathrm{CaO}$-containing titania, Biomaterials 23 (1) (2002) 167-172

[40] J. Zhang, et al., Calcium phosphate/chitosan composite coating: Effect of different concentrations of $\mathrm{Mg}^{2+}$ in the m-SBF on its bioactivity, Appl. Surf. Sci. 280 (2013) 256-262.

[41] M. Kawashita, et al., Apatite-forming ability of carboxyl group-containing polymer gels in a simulated body fluid, Biomaterials 24 (14) (2003) 2477-2484.

[42] Z. Huan, J. Chang, Self-setting properties and in vitro bioactivity of calcium sulfate hemihydrate-tricalcium silicate composite bone cements, Acta Biomater. 3 (6) (2007) 952-960.

[43] M.V. Cabañas, L.M. Rodríguez-Lorenzo, M. Vallet-Regí, Setting behavior and in vitro bioactivity of hydroxyapatite/calcium sulfate cements, Chem. Mater. 14 (8) (2002) 3550-3555.

[44] L.L. Hench, Bioceramics: from concept to clinic, J. Am. Ceram. Soc. 74 (7) (1991) 1487-1510.

[45] H. Takadama, et al., X-ray photoelectron spectroscopy study on the process of apatite formation on a sodium silicate glass in simulated body fluid, J. Am. Ceram. Soc. 85 (8) (2002) 1933-1936. 